\title{
Morphological Variability in Teliospores of Puccinia penniseti
}

\author{
By R. G. KAPOORIA \\ Njala University College, University of Sierra Leone, Freetown, Sierra Leone
}

(Received 22 January 1973; revised 23 March 1973)

\begin{abstract}
SUMMARY
Pure-line isolates of Puccinia penniseti Zimm. collected from various localities were induced to develop telia by growing infected plants of Pennisetum typhoides Stapf and Hubb. Telia developed not only normal two-celled teliospores but also occasionally one- and three-celled and rarely four- and five-celled teliospores. The shape and size of teliospores varied considerably in one-, two- and threecelled teliospores. Three morphological forms of Puccinia penniseti have been distinguished on the basis of this variability.
\end{abstract}

\section{INTRODUCTION}

Spore characteristics have been extensively used in fungi to distinguish different morphological forms of a pathogen. Stakman, Piemeisal \& Levine (I9I9) noted considerable differences in the morphology of urediospores of wheat rust. Dalela \& Sinha (1957) studied urediospore characters of Puccinia penniseti and found three distinct morphological forms of the pathogen. The use of urediospores in determining morphological forms in rust fringe is quite common, apparently because of the relative ease with which they can be obtained. In contrast, it is not always possible to get plentiful teliospores and hence these are less frequently employed in the recognition of morphological forms. In this study, morphological characteristics of teliospores of Puccinia penniseti Zimm., the fungus causing rust disease in Pennisetum typhoides Stapf and Hubb., have been studied with a view to determining the presence of morphological forms of the pathogen.

\section{METHODS}

Specimens of fresh uredial materials were collected from different localities around Agra (north) and Coimbatore (south), India. Single spore isolates of these were multiplied on Pennisetum typhoides var. Agra local. Development of telia was induced by growing plants in a greenhouse during the colder months of November to February, when they developed telia rapidly (Kapooria, I970). The telia were scraped from infected tissue and teased in a drop of water on a microscope slide. One hundred random observations were made of each isolate. The significance of measurements was determined at the $5 \%$ probability level. Camera-lucida drawings of unusual teliospores were also made.

\section{RESULTS}

Teliospore septation. Puccinia species usually produce two-celled teliospores. Table I shows that teliospores developing in a sorus were sometimes also one- and three-celled. 

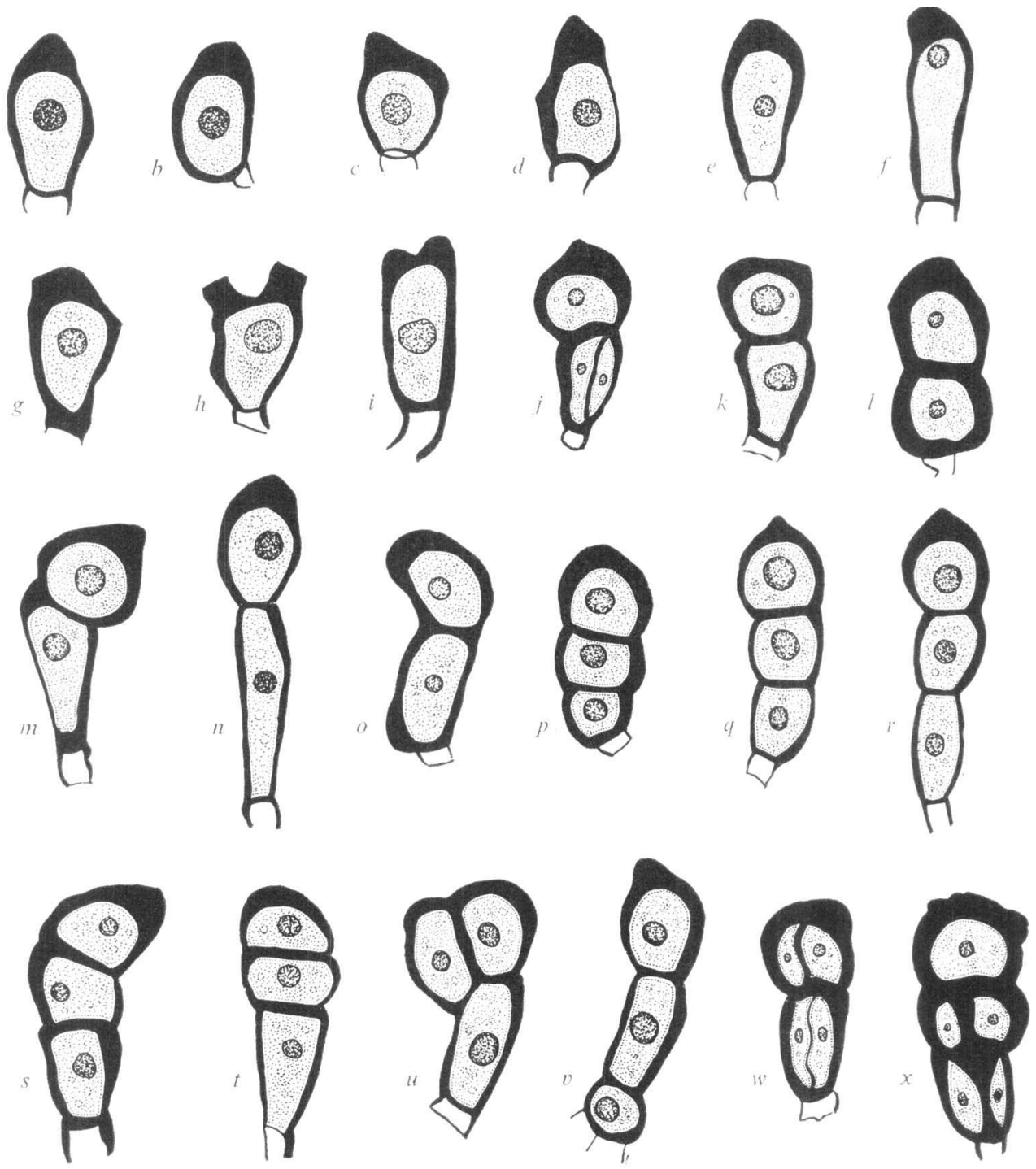

Fig. 1. Different types of teliospores of Puccinia penniseti Zimm. (a-i) One-celled teliospores; $(j-o)$ two-celled teliospores; $(p-v)$ three-celled teliospores; $(w-x)$ four- and five-celled teliospores respectively.

Four- and five-celled teliospores were observed infrequently. The chances of appearance of one- and three-celled teliospores in a sorus are the same. Fig. I shows the variety of shapes that teliospores of Puccinia penniseti exhibited.

Measurements of various dimensions in two-celled teliospores. The various dimensions of teliospores varied considerably (Table 2).

Measurements of various dimensions in one- and three-celled teliospores. The means of various dimensions of one- and three-celled teliospores varied in different rust isolates. The mean length and width in one-celled teliospores varied from 35.9 to $5 \mathrm{I} \cdot 6$ and $17 \cdot 4$ to $5 \mathrm{I} \cdot 6 \mu \mathrm{m}$ 
Table I. Distribution of one-, two-, three-, four- and five-celled teliospores observed in different isolates of Puccinia penniseti Zimm

$\begin{array}{ccccccc}\text { Isolate } & \text { I-Celled } & \text { 2-Celled } & \text { 3-Celled } & \text { 4-Celled } & \text { 5-Celled } & \text { Total } \\ \text { I } & 3 & 93 & 4 & 0 & 0 & 100 \\ 2 & 2 & 96 & 2 & 0 & 0 & 100 \\ 3 & 6 & 81 & \text { II } & \text { I } & \text { I } & 100 \\ 4 & 0 & 96 & 4 & 0 & 0 & 100 \\ 5 & 9 & 90 & \text { I } & 0 & 0 & 100\end{array}$

Table 2. Measurements (in $\mu \mathrm{m}$ ) and length/width (l/w) ratios of two-celled teliospores in different isolates of Puccinia penniseti Zimm (mean of 100 observations)

\begin{tabular}{|c|c|c|c|c|c|}
\hline \multirow[b]{2}{*}{ Factors } & \multicolumn{5}{|c|}{ Isolates } \\
\hline & $\mathbf{I}$ & 2 & 3 & 4 & 5 \\
\hline Length & $68 \cdot 2$ & $65 \cdot 3$ & $59 \cdot 5$ & $65 \cdot 9$ & $62 \cdot 6$ \\
\hline Width & $22 \cdot 4$ & $23 \cdot 8$ & $22 \cdot 7$ & $22 \cdot 8$ & $22 \cdot 2$ \\
\hline Wall thickness & $I \cdot I$ & $1 \cdot 2$ & $2 \cdot 6$ & $3 \cdot 0$ & $2 \cdot 9$ \\
\hline Pedicel length & II $\cdot 2$ & $9 \cdot 3$ & $9 \cdot 0$ & $9 \cdot 3$ & $9 \cdot 4$ \\
\hline Apex thickness & $6 \cdot 7$ & $6 \cdot 9$ & 5.9 & $7 \cdot 0$ & $7 \cdot 7$ \\
\hline $1 / \mathrm{w}$ ratio & $3 \cdot 0$ & $2 \cdot 7^{*}$ & $2 \cdot 6^{*}$ & $2 \cdot 4$ & $2 \cdot 8^{*}$ \\
\hline
\end{tabular}

respectively, and the same dimensions in three-celled teliospores varied from $59 \cdot 9$ to $86 \cdot 2$ and 22.6 to $32.4 \mu \mathrm{m}$ respectively. Other dimensions, such as wall thickness, pedicel length, and apex thickness, also varied in one- and three-celled teliospores.

Determination of morphological forms of Puccinia penniseti. The length/width ratios of teliospores of the five rust isolates were studied. The results in Table 2 show that the five rust isolates differed in these.

\section{DISCUSSION}

Three distinct morphological forms of Puccinia penniseti have been identified on the basis of the present observations. Ramakrishanan \& Sundaram (1956) distinguished two races of $P$. penniseti based upon their studies on materials occurring in nature. Dalela \& Sinha (1958, 1959) indicated the presence of specialization but failed to identify the races. Later work of Dalela \& Sinha (I962) showed $P$. penniseti to be homothallic. The production of new races of the pathogen by hybridization would thus be ruled out. Since several additional causes of variability in pathogens, especially in rust fungi, have been suggested (Christensen, 196I), physiological as well as morphological forms of $P$. penniseti might arise in a variety of ways. Dalela \& Sinha (1957) identified three distinct morphological forms of $P$. penniseti on the basis of biometric variations of urediospores.

That teliospores can also constitute a reliable basis for the distinction of morphological forms of rust genera is indicated by Guyot (1938, 1945), Guyot, Massenot, Montegut \& Saccus (1948) and Savile \& Corners (I95I). Size as well as shape variations have been found to be useful taxonomic criteria (Warren, I898; Hume, I 899; McAlpine, I906; Taubenhaus, I9I I and Arthur 1929). Such variations in size and shape of spores occur not only in geographically isolated collections but also within the same sorus (Baxter, 1955). The presence of one- and more-celled teliospores in Puccinia penniseti is not remarkable; Benada (1960) has reported the presence of multicellular teliospores in stem rust of wheat 
where they occur with normal spores in some pustules and alone in others, and abnormal teliospores have also been reported by Payak (1962) in $P$. thwaitesii.

The causes of abnormality in teliospores are unknown, though Arthur (I929) advanced several explanations. That the abnormal teliospores constitute accidental structures without any genetical significance is difficult to substantiate at present. There is some evidence to suggest that certain isolates of Puccinia penniseti have an intrinsic ability to produce more abnormal teliospores than others.

I am indebted to Professor S. Sinha, Principal, Agra College, Agra, India, for suggesting the problem, and to Dr S. N. Bhardwaj, Plant Physiologist, Indian Agricultural Research Institute, New Delhi, India for help in statistical analysis of the data.

\section{REFERENCES}

ARthur, J. C. (1929). The Plant Rusts (Uredinales). New York: John Wiley. London: Chapman and Hill Ltd.

Baxter, J. W. (1955). Species of Puccinia on Salvia in Europe, Asia and Africa. Mycologia 47, 225-232.

BenadA, J. (1960). Vicebunecene Zimni vytrusy yzi travni. Puccinia graminis Pers. Česka mykologie, Praha I4, I45-I 47 .

Christensen, J. J. (196I). Somatic variations in the rust fungi. Recent Advances in Botany 5, 57I-574.

Dalela, G. G. \& Sinha, S. (1957). Further studies on biometry of uredospores of Puccinia penniseti Zimm. Proceedings National Academy of Sciences, India B 27, 245-250.

Dalela, G. G. \& Sinha, S. (1958). Studies on physiologic specialization in Puccinia penniseti Zimm. on Pennisetum typhoides Stapf and Hubb. Proceedings 45th Indian Science Congress 3 (Abstr.), 275.

Dalela, G. G. \& Sinha, S. (I959). A further contribution to the study of physiologic specialization in Puccinia penniseti Zimm. on Pennisetum typhoides Stapf and Hubb. Proceedings 46 th Indian Science Congress 3 (Abstr.), 338.

Dalela, G. G. \& Sinha, S. (1962). Homothallism in Puccinia penniseti Zimm., a long cycled rust and the function of pycnia. Indian Phytopathology 15, I56-16I.

Guyot, A. L. (1938). Les Uredinées (rouilles des végétaux) Uromyces, p. 439. Paris: Paul Lechevalier.

GuYot, A. L. (I945). Étude biometrique de Puccinia graminis (rouille noire des Graminées). Compte rendu de l'Académie des sciences 220, 19, 700-70I.

Guyot, A. L., Massenot, M., Montegut, J. \& Saccas, A. (1948). A propos de la rouille jaune des Graminées (Puccinia glumarum). Compte rendu de l'Académie des sciences 227, I, 83-85.

HUme, H. H. (1899). Some peculiarities in Puccinia teleutospores. Botanical Gazette 28, 418-423.

KAPOORIA, R. G. (1970). On the purification technique and production of telia in certain isolates of Puccinia penniseti. Plant Disease Reporter 54, 646-647.

McAlpine, D. (1906). The Rusts of Australia. Melbourne: R. S. Brain.

PayaK, M. M. (1962). Acytological study of Puccinia thwaitesii Berk. Indian Phytopathology 15, 37-49.

Ramakrishnan, T. S. \& Sundaram, N. V. (1956). Further studies on Puccinia penniseti Zimm. Proceedings Indian Academy of Sciences, B 3, 190-196.

SAVILE, D. B. O. \& CoRness, I. L. (1951). The rusts of Armeria and Limonium in North America. Mycologia 43, I86-I95.

Stakman, E. C., Piemeisal, F. J. \& Levine, M. N. (1919). Effect of certain ecological factors on the morphology of the urediniospores of Puccinia graminis. Journal of Agricultural Research 16, 43-77.

Taubenhaus, J. (I9II). A contribution to our knowledge of the morphology and life history of Puccinia malvacearum Mont. Phytopathology I, 55-62.

WARREN, J. A. (1898). Note on the variations in the teleutospores of Puccinia windsoriae. American Naturalist 32, 779-78I. 